\title{
The effectiveness of Emotionally-Focused couple therapy on the style of attachment and sexual satisfaction of couples
}

\author{
Fatemeh Ghaznavi Khezrabadi $^{1}$ (iD), Mandana Niknam ${ }^{2}$ \\ ${ }^{1}$ Department of Psychology and Education, Faculty of Human Science, Khatam University, Tehran, Iran \\ ${ }^{2}$ Corresponding author; Department of Psychology and Education, Faculty of Human Science, Khatam University, Tehran, Iran \\ Tel:+982189170000_Fax:+982189174500_Email:m.niknam@khatam.ac.ir
}

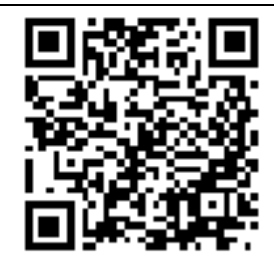

Citation Niknam M, Ghaznavi Khezrabadi F. [The effectiveness of Emotionally-Focused couple therapy on the style of attachment and sexual satisfaction of couples]. J Birjand Univ Med Sci. 2019; 26(3): 213-25. [Persian]

DOI http://doi.org/10.32592/JBirjandUnivMedSci.2019.26.3.103

Received: May 28, 2018

Accepted: April 13, 2019

\begin{abstract}
Background and Aim: A successful marriage is often accompanied by both partner consent to sex, on the other hand, the structure of a balanced family is based on sound marital relations. One of the most important factors in strengthening this relationship, is the attachment style of couples. The purpose of this study was Effectiveness of emotionally-focused couple therapy on the style of attachment and sexual satisfaction of couples.

Materials and Methods: The method of study was quasi-experimental with pretest-posttest design with control group. The study population consisted of all couples referring to clinic in Neyshabur city in 2016. Based on inclusion criteria, 32 couples were selected by convenience sampling and randomly divided into intervention $(n=16)$ and control $(n=16)$ groups. For data collection, Haddison and Kruskaph Sexual Satisfaction Index and Collins and Read Adolescents Adjustment Scale were used. Paired t-test and covariance analysis were used for data analysis.

Results: The results of the analysis of variance showed that in post-test, there was a significant difference between sexual satisfaction and attachment style of the intervention group and control group $(\mathrm{P}<0.05)$. The results showed that emotional-couple therapy had a significant effect on sexual satisfaction and subscales of sexuality and sexual intimacy, but it had no significant effect on the subscales of sexual behavior and quality of sexual relations $(\mathrm{P}>0.05)$. Also, it had a significant effect on attachment style and its subscales of proximity, dependency, and anxiety.
\end{abstract}

Conclusion: The findings of this study indicate the beneficial effects of emotional-couple therapy in improving attachment style and marital satisfaction of couples.

Key Words: Emotionally Focused Couple Therapy; Sexual Satisfaction; Attachment Style 


\section{اثربخشى زوجدر مانى هيجانمدار بر سبك دلبستگى و رضايتمندى جنسى زوجين}

فاطمه غزنوى خضر آبادى 'Did)، ماندانا نيكنام

\section{جكيده}

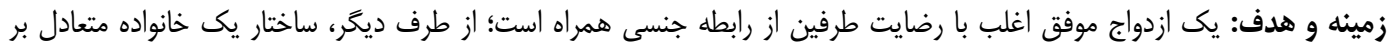

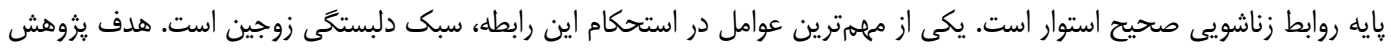

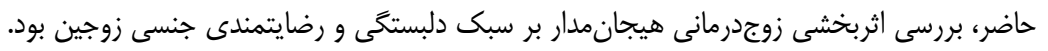

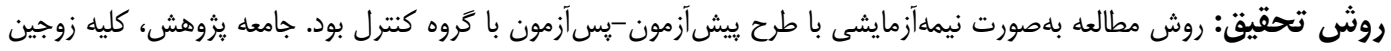

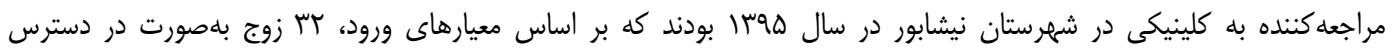

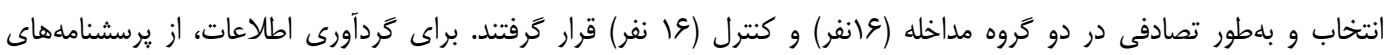

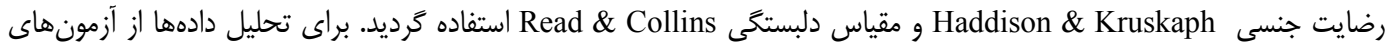
تىزوجى و تحليل كواريانس استفاده شد.

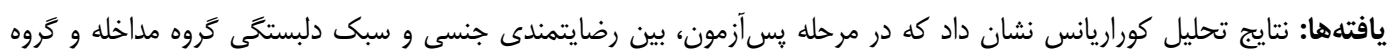

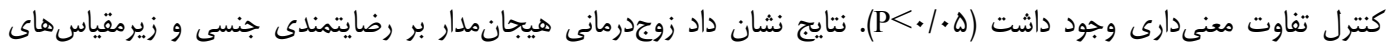

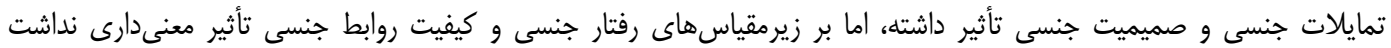

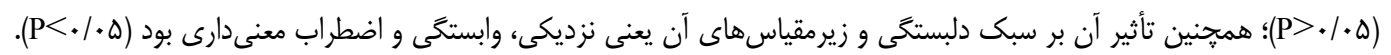

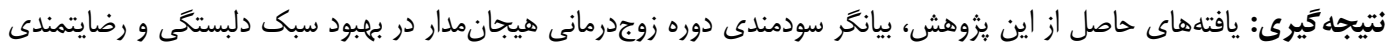
جنسى زوجين است.

$$
\begin{aligned}
& \text { وازههاى كليدى: زوجدرمانى هيجانمدار؛ رضايتمندى جنسى؛ سبك دلبستخى }
\end{aligned}
$$

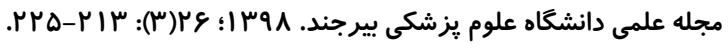

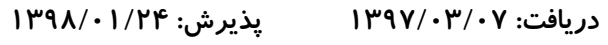

' "كروه روانشناسى و علوم تربيتى، دانشكده علوم انسانى، دانشكاه خاتم، تهران، ايران

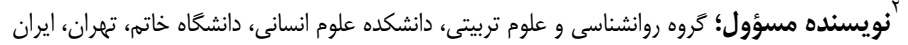

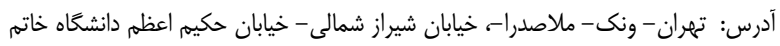

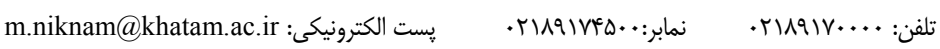


نايمن سطوح پايينتر رضايت زناشويى را گزارش دادهاند؛ تا

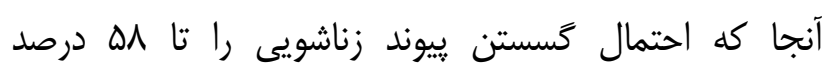

در بين نيازهاى زيستى، انخيزه جنسى آميختخى عميقى با

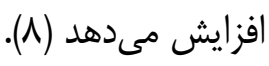
رويكردهاى مختلفى در زمينه زوجدرمانى وجود دارد له كه

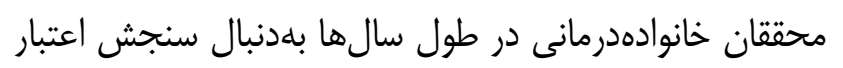

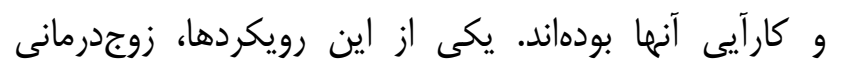
هيجانمدار (EFT) Emotional-focused therapy) است. زوجدرمانى هيجانمدار، رويكردى يكيارخه از تلفيق سله

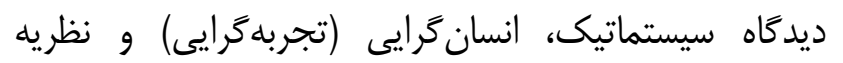

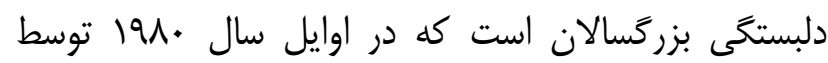
Johnson

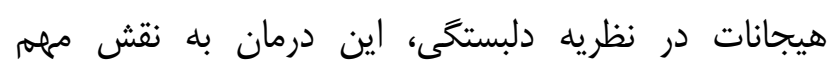

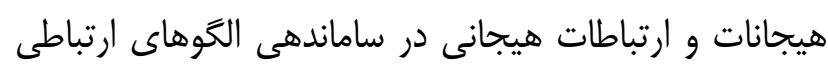

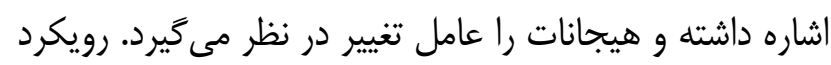

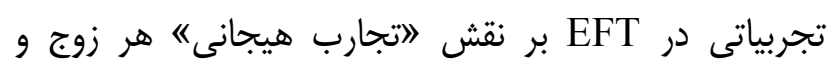

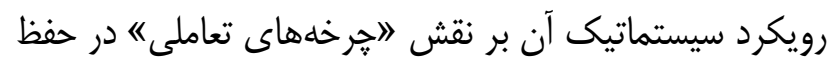

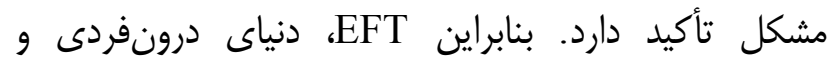

بينفردى را يكيار خه مى مازد (9) (9).

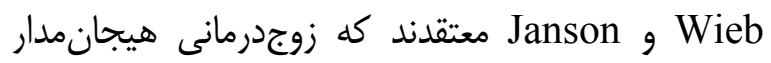
بلعلت ساختارمندبودن و داشتن برنامه درمان مرحله به مرحله

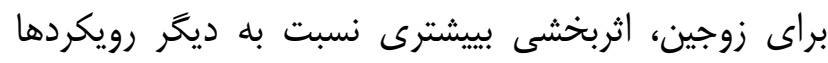

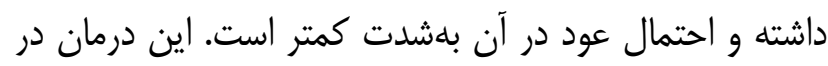

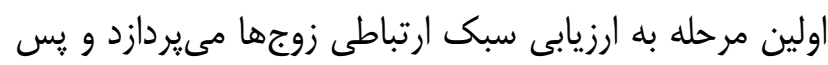

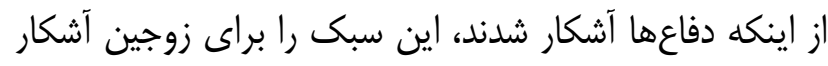

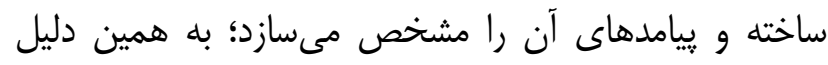

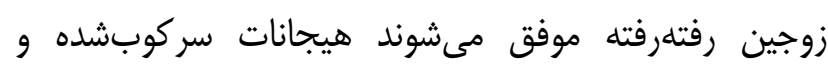

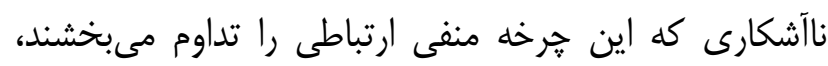

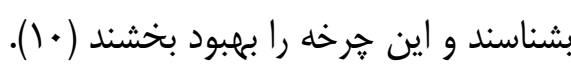

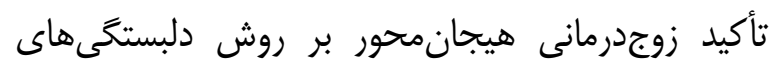

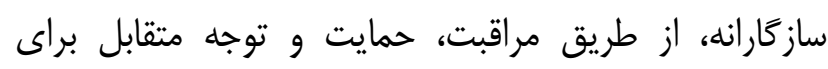
نيازهاى خود و همسر است. اين رويكرد معتقد است كهان آنه

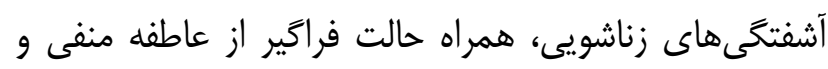

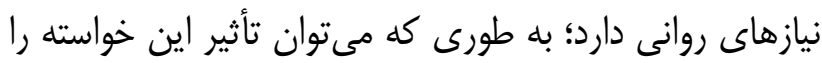

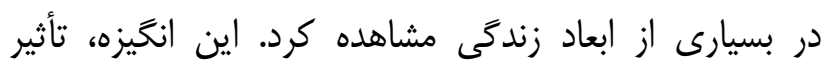

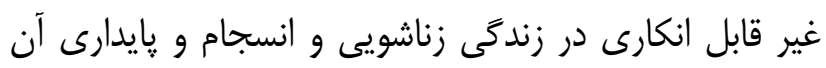

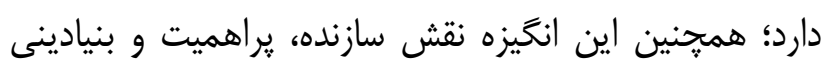
در سير بلهوى سلامت و تعادل روانى داراست؛ بنابراين

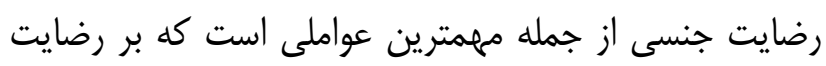

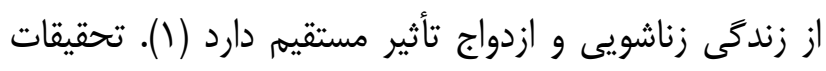
متعددى كه در مورد عوامل مرتبط با ازدواج انجام كرفته زتأه

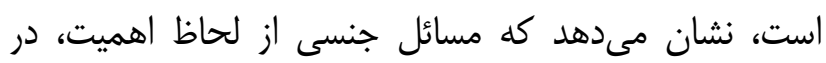
رديف مسائل درجه اول زوجين قرار دارد (َ، ؟). عدهاى از مجققان معتقدند كه سبك دلبستخى زوجن زوجين

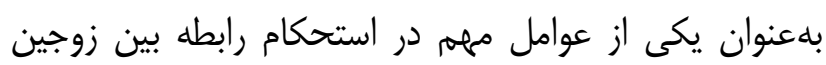

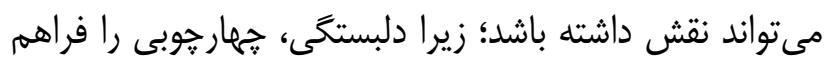

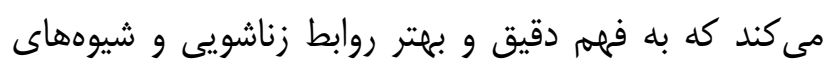
مقابله با تعارض زوجين كمى مى كند (أ). دلبستخى، رابطه

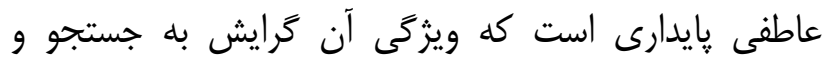

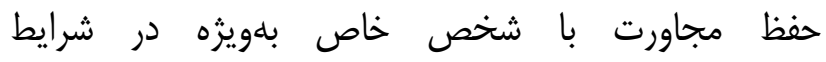

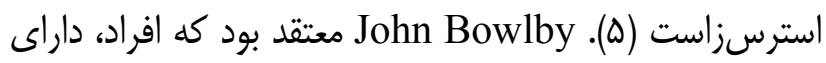

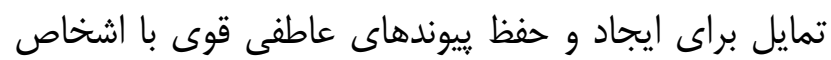

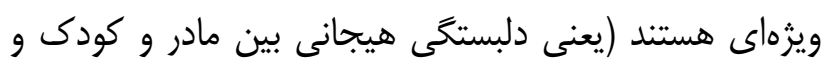

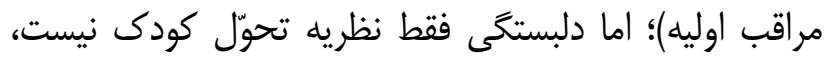

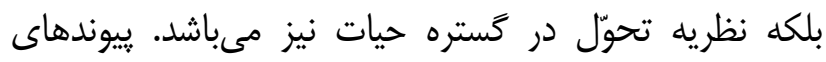

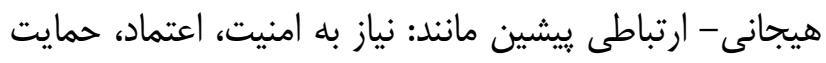

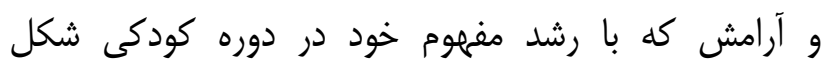
مى گيرد، اثرات بلندمدتى در كيفيت روابط بزر گسالى دارد (؟). مطالعات زيادى به بررسى اهميت دلبستخى و ور رضايتمندى

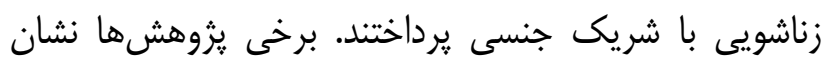

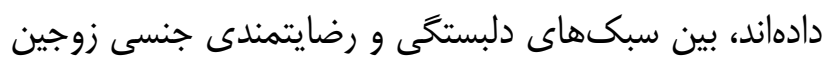

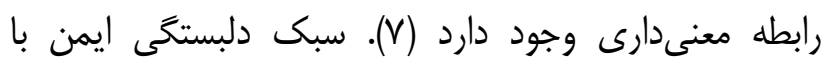

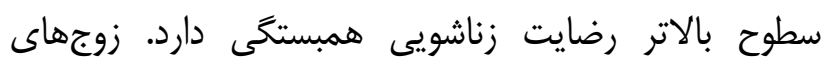


نشان داد كه مداخله درمانى هيجانمدار، در افزايش

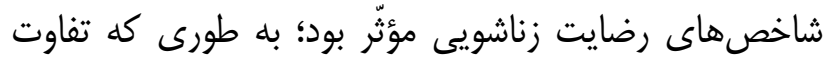

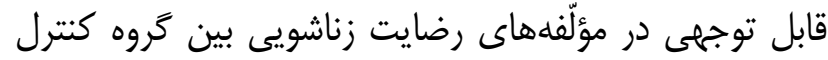

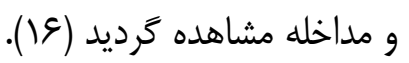

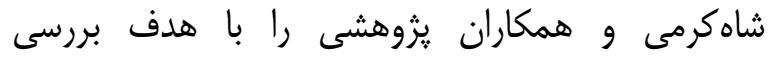

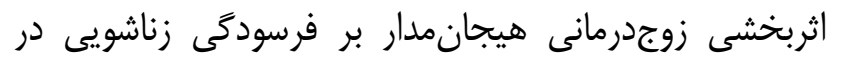

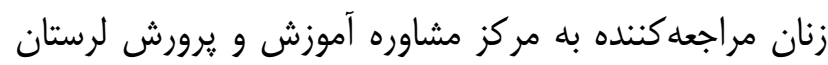

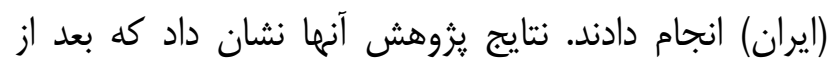
مداخله زوجدرمانى هيجانمدار، تفاوت معنى دارى بين دو گروها

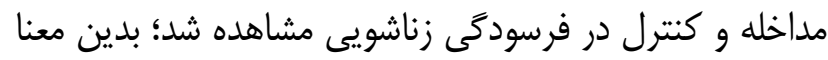

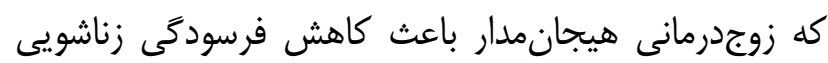
زنان در گروه مداخله گرديد (IV) Pر يزوهشى تحت عنوان درمان هيجانمدار

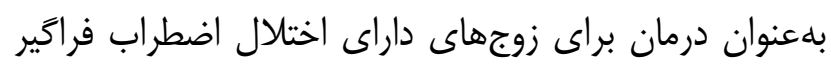

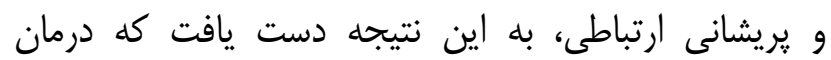

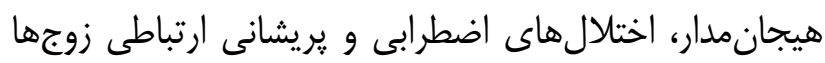

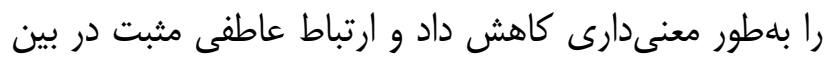
آنها رشد كرد (1) (1). از أنجا كه هيجانات، نقش كليدى در روابط زوجين ايفا

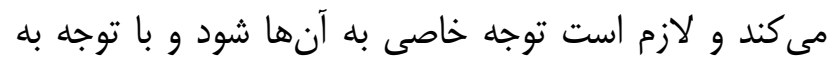
اهميت سبك دلبستخى و رضايتمندى جنسى بر كيفيت روابط لوان زوجين و خانواده و عدم توانايى زوجين در ابراز و بيان

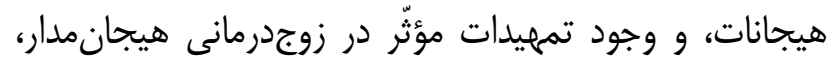

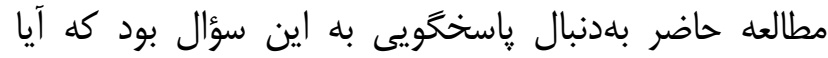

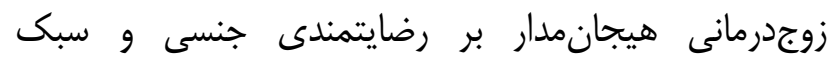
دلبستخى زوجين تأثير دارد؟

\section{روش تحقيق}

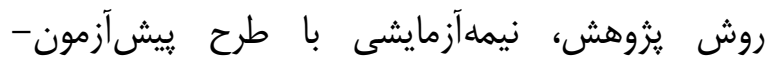

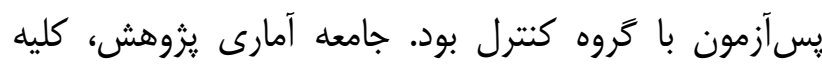

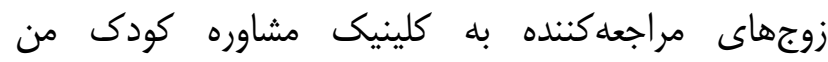

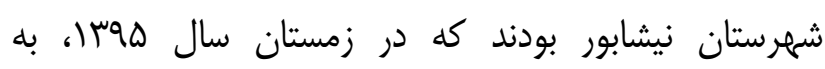

آسيبهاى دلبستخى ايجاد مىشود و ادامه يِيدا مى كند (1).

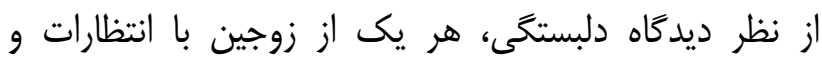

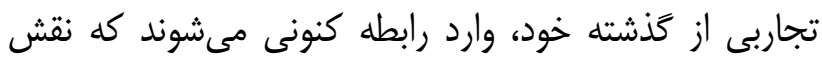

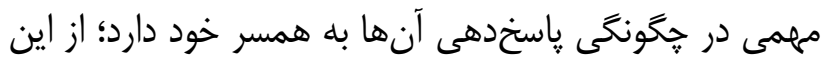

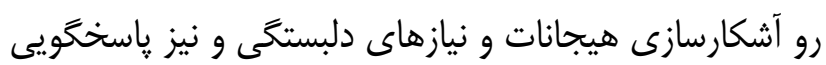

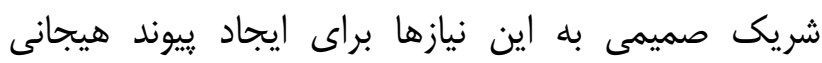

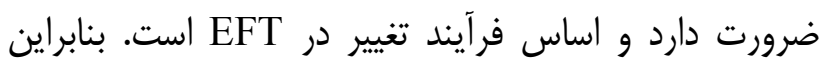

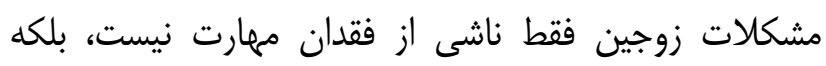

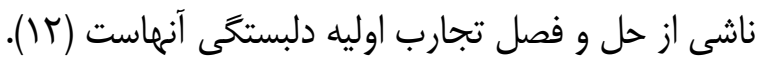

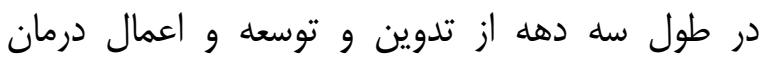

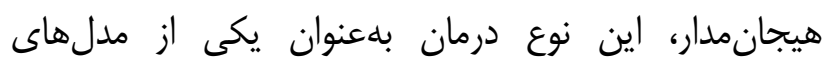

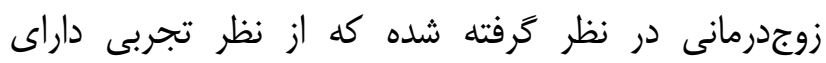

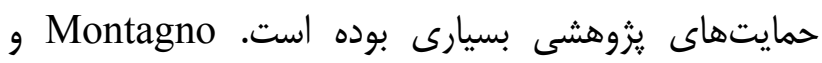

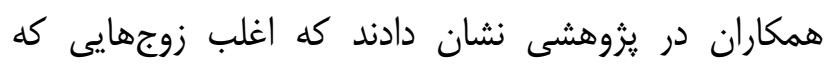

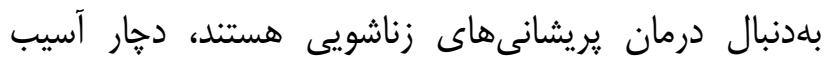

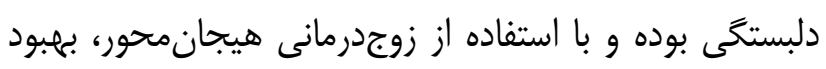
قابل توجهى در رابطه بعد از درمان نشان دادهاند؛ همجنين نتايج در طول سه سال بيگيرى، نشاندهنده بهبود در تنظيم

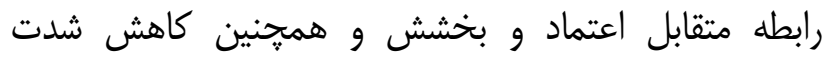

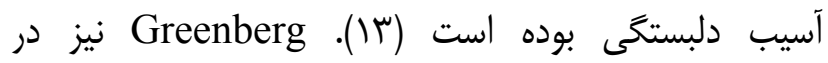

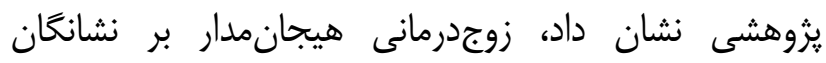
افسردگى و اضطراب زوجين تأثير مثبت معنى دارى داشته

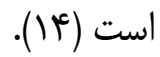

رمضانى و همكاران، يزوهشى را با هدف مقايسه

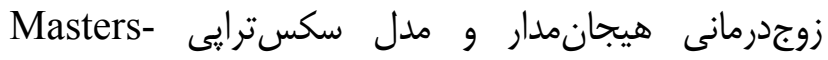
Johnson's

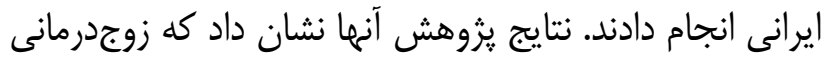

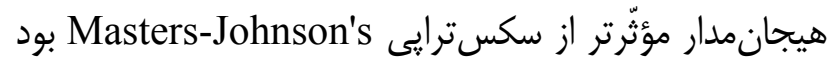

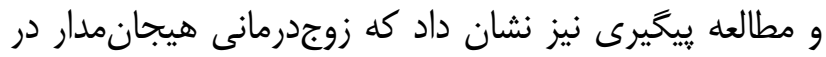

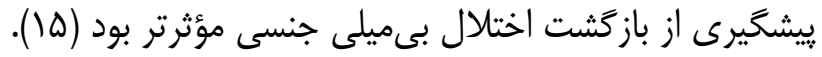

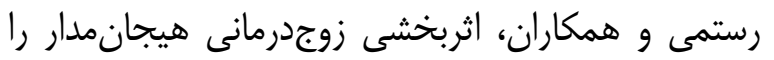
در بهبود رضايت زناشويى بررسى كردند. نتايج مطالعه آنها 
درجلبندى شده است و رضايتمندى جنسى را در دو بعد

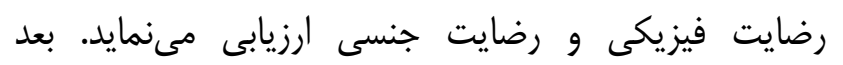

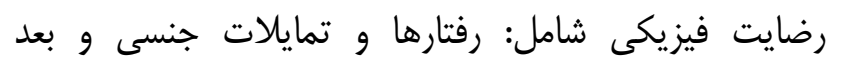

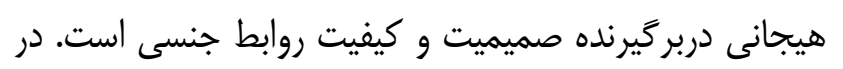

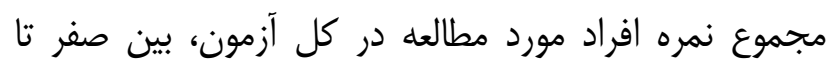
IVD

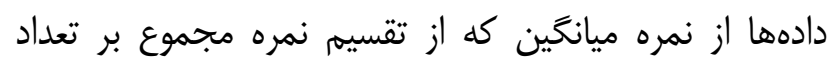

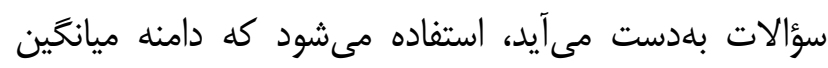

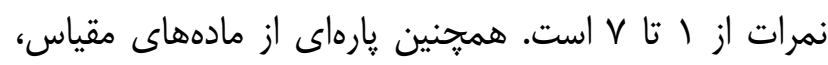

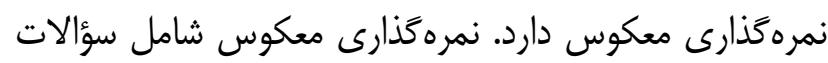

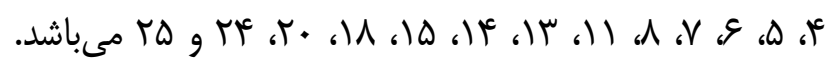
نمره بالا در اين مقياس منعكس كننده رضايت جنسى است

Haddison

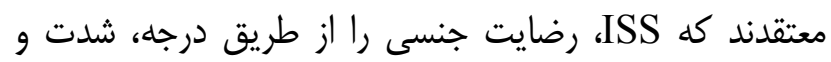

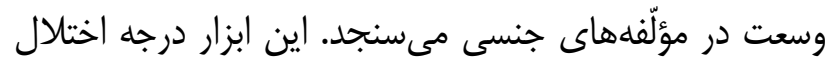

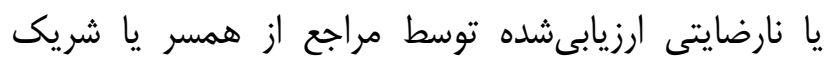

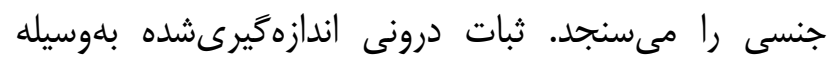

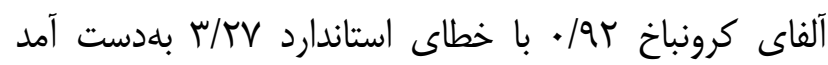

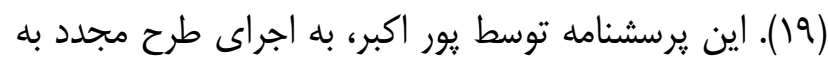
فاصله ها روز براى بررسى وضعيت هنجارى مقياس استفاده

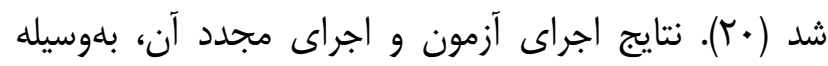

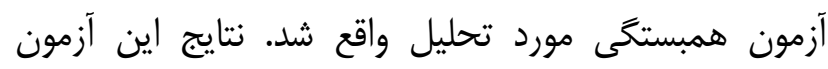

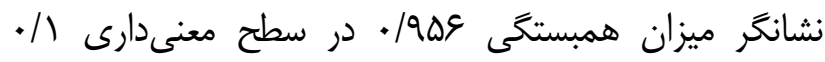

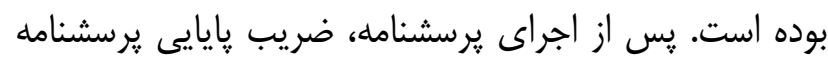

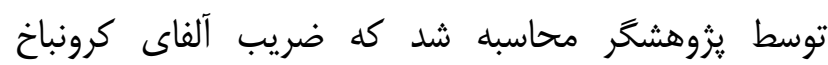

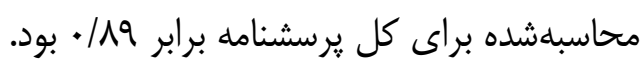

\section{مقياس دلبستخى بزركسالان (نسخه تجديد نظر شده)}

:(RAAS) Revised Adult Attachment scale

مقياس دلبستخى بزركسالان، ابتدا در سال • 199 بلوسيله

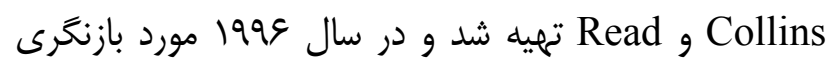
قرار گرفت. مبناى نظرى اين آزمون نظريه دلبستخى است.
فراخوان يزوهشَّ براى شركت در يزوهش، ياسخ مثبت

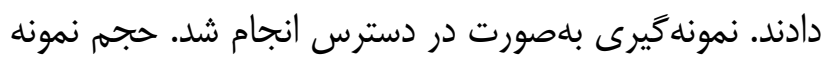
در اين يزوهش با توجه به مقادير يزوهش راهنما با ميانخين

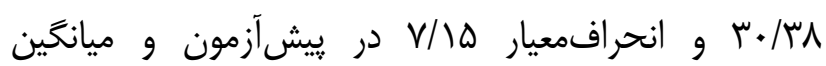

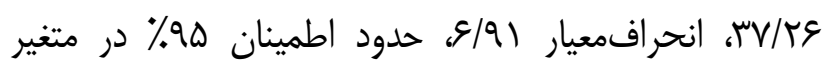

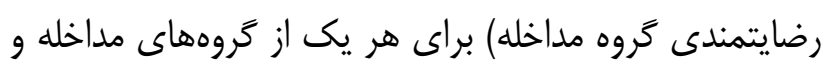

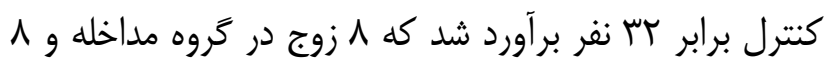

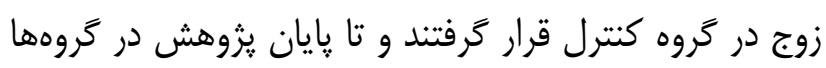
باقى ماندند. مركز مشاوره كودى من، خدمات متعدد روانشناختى و

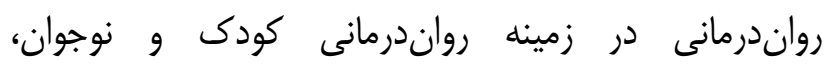

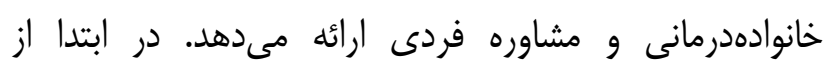

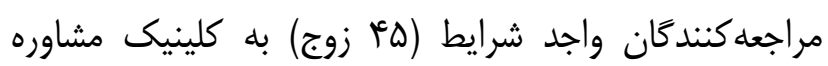
كودى من شهرستان نيشابور، مصاحبه اوليه گرفته شد؛ سيس

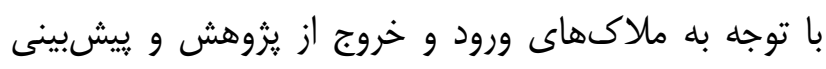

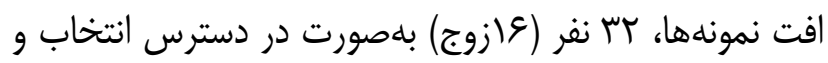
بلهصورت تصادفى ساده در زروههاى كنترل و مداخله قرار بلنه كرفتند.

r. معيارهاى ورود به بروهش شامل: داشتن سن حداقل

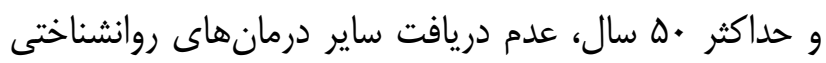

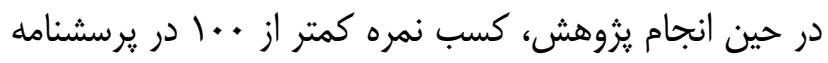

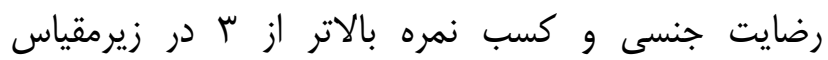

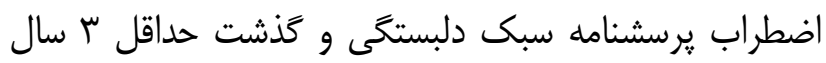
از ازدواج زوجين و معيارهاى خروج از يزوهش شامل: خروسئن داوطلبانه، داشتن رابطه فرا زناشويى و تصميم به طائ حلاق بود. در يزوهش حاضر از ابزارهاى زير براى گردآَورى دادهانها

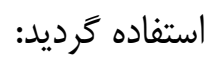

\section{Index of Sexual Satisfaction شاخص رضايت جنسى}

شاخص رضايت جنسى در سال 1911) توسط Haddison \& Kruskaph حاوى فr سؤال است كه با مقياس Vدرجهاى ليكرت 


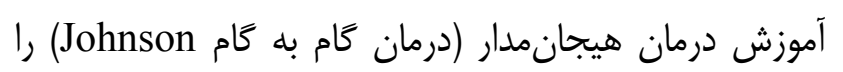

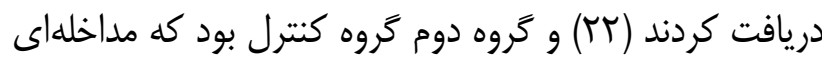

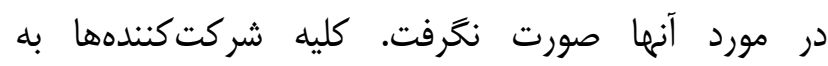
يرسشنامههاى يثوهش در دو نوبت، ييش از آغاز جلسات

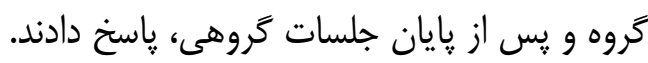

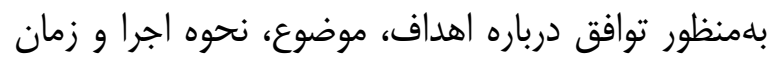

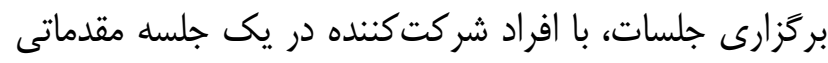

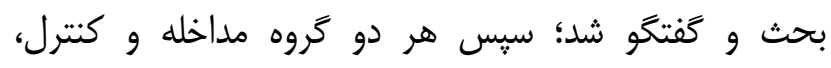

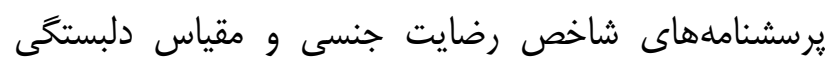

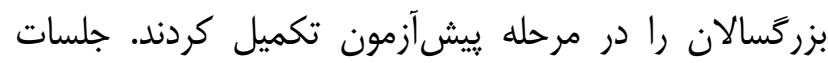

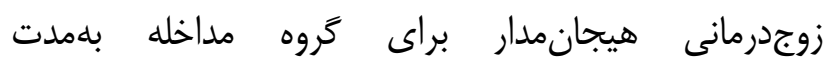

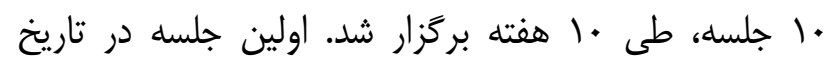

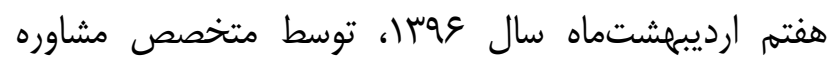

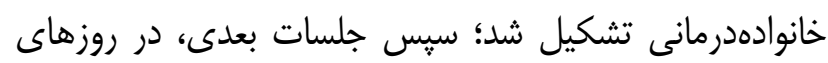

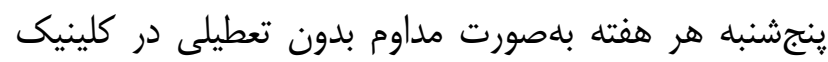
روانشناسى و مشاوره كودى من شهرستان نيشابور بركزار شد.

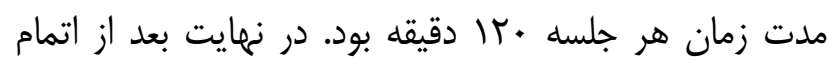

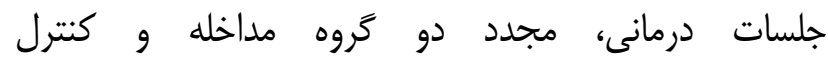

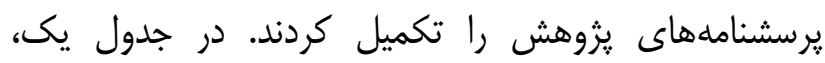

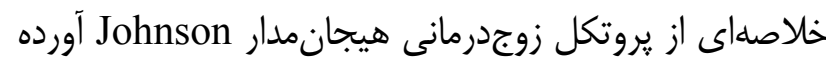

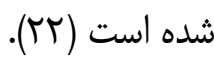
براى اجراى ملاحظات اخلاقى، موارد زير در يزوهش

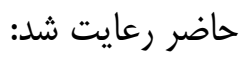

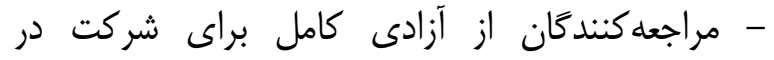

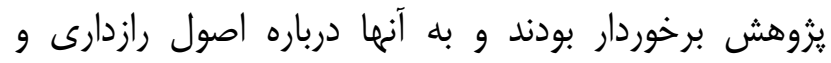
محرمانهبودن اطمينان داده شد. -

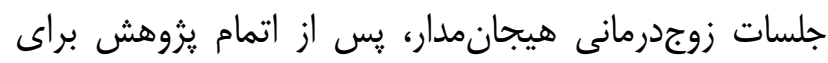

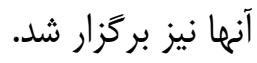

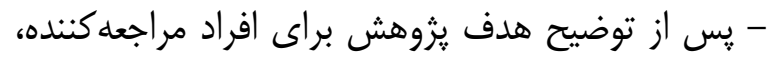

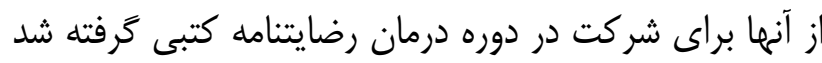

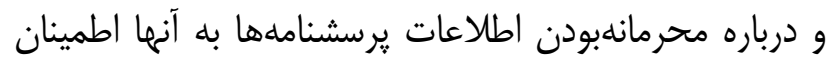

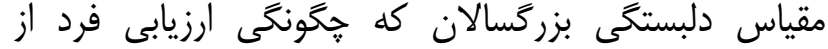
مهارتهاى ارتباطى و سبك رابطه صميمانه را مورد بررسى

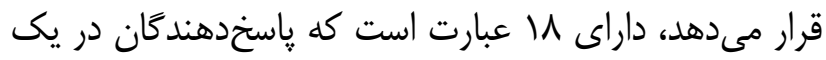

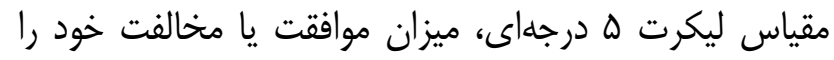

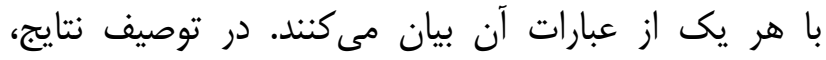

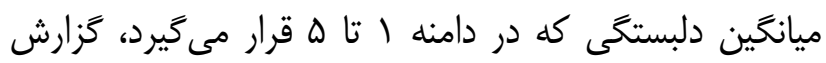

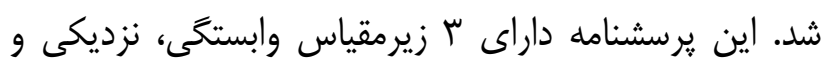

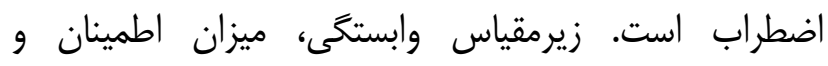

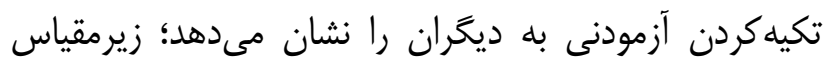

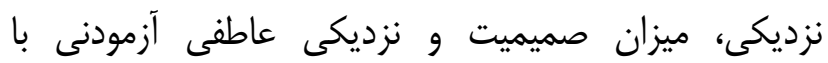

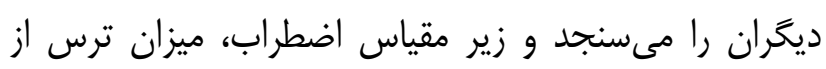

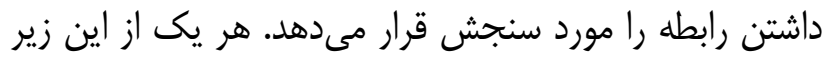

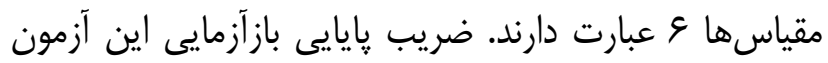
براى هر يك از ب زيرمقياس نزديكى، وابستخى و اضطراب دابل

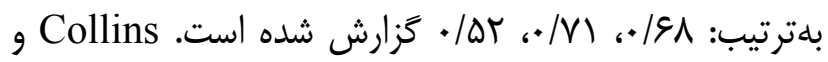
ز Read زيرمقياسهاى نزديكبودن، وابستكى و اضطراب در فاصله

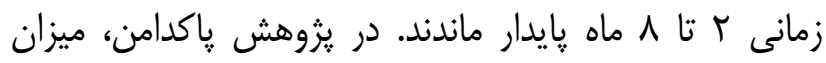

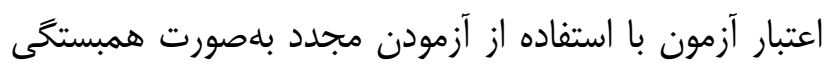

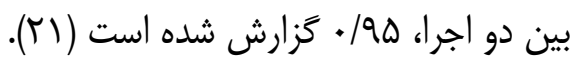

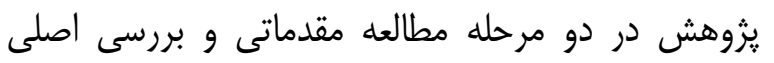

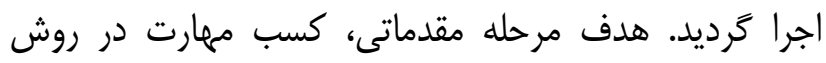

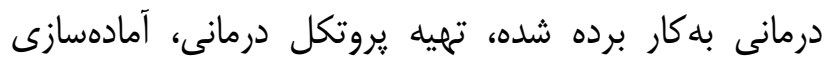

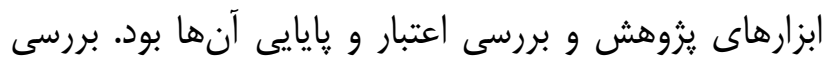
اصلى، يس از دادن فراخوانهاى الكترونيكى و نوشتارى انجام شد. افراد شركتكننده بر اساس ملاكىهاى ورى ورود به ئروهش،

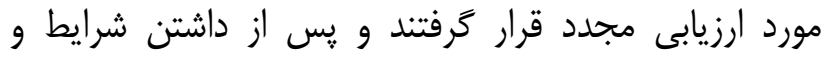

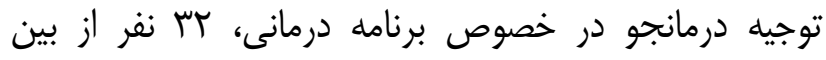

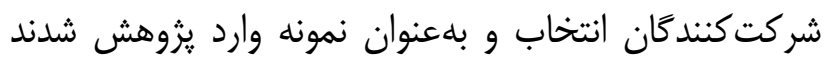
كه سيس بلهصورت تصادفى در دو گروه مداخله و كنترل قرار كرفتند. گروه مداخله شامل عا شركت كننده (^ زوج) بود كه 
كمى نرمافزار SPSS (ويرايش ه T) انجام كرديد. سطح

خطاى آلفا در اين يزوهش مقدار حداكثر هـ • • تعيين شد.

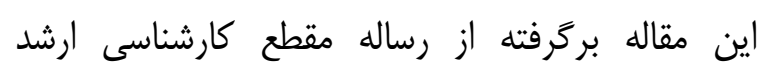

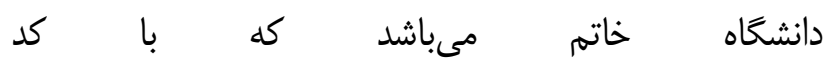
IR.NUMS.REC.1397.024 در كميته اخلاق دانشخاه علوم يزشكى نيشابور مورد تأييد قرار كرفته است.
-كليه يرسشنامهها بدون نام و با استفاده از كد، تكميل

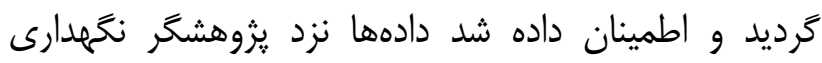

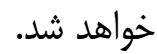

در توصيف دادهها، ويزگى هاى جمعيتشناختى و توصيف نمرات هر يك از متغيرهاى يثوهش بله تفكيك رَروهها

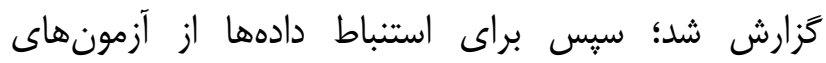

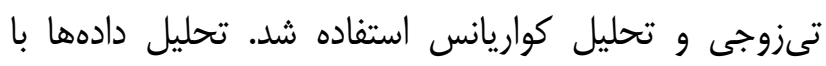

جدول ا - خلاصه يروتكل زوجدرمانى هيجانمدار Johnson

\begin{tabular}{|c|c|c|}
\hline محتوى جلسه & 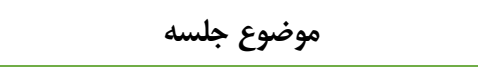 & رديف \\
\hline 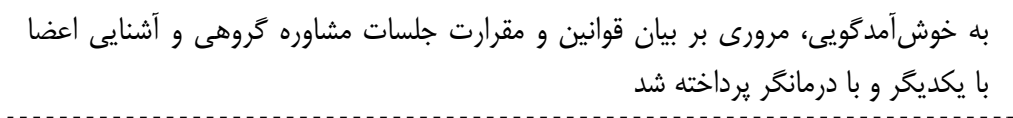 & ايجاد اتحاد درمانى & 1 \\
\hline 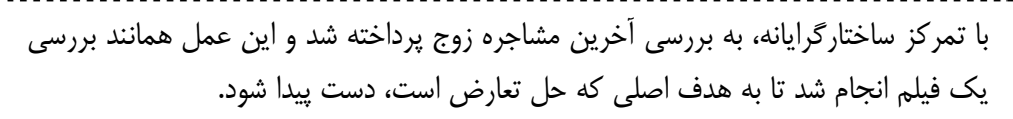 & كشف و روشنسازى پرخه عاملى منفى & r \\
\hline 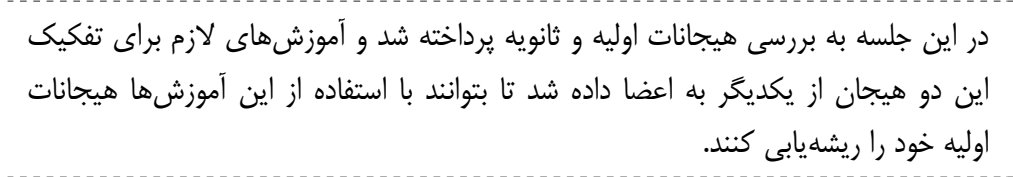 & دستيابى به هيجانات اوليه & r \\
\hline 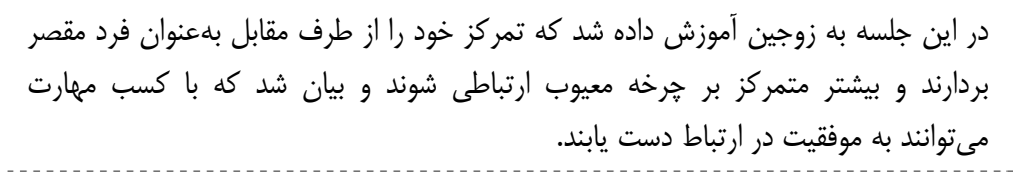 & قابدهى مجدد به مشكل & r \\
\hline 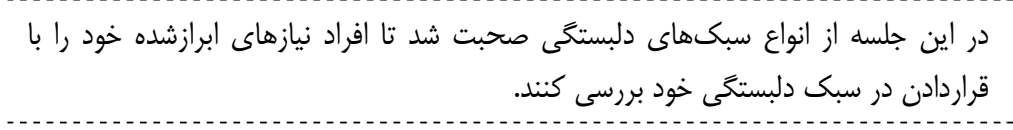 & افزايش شناخت در مورد هيجانها، نيازها و & $\Delta$ \\
\hline 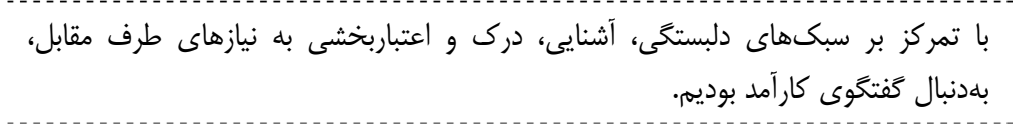 & افزايش يذيرش و درك همسران از يكديكر & \& \\
\hline 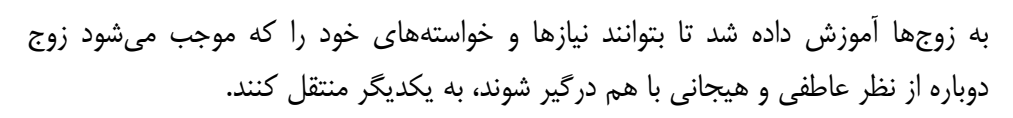 & درگيرى عاطفى و هيجانى زوجها با & v \\
\hline 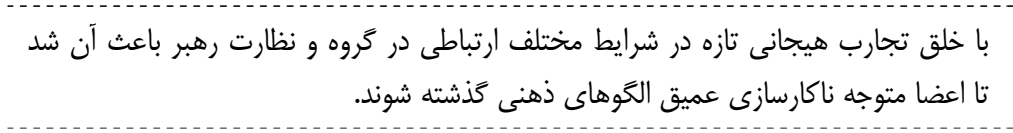 & تسهيل هديدآيى راهكارهاى تازه براى حل مهنه ارتباطى & $\wedge$ \\
\hline 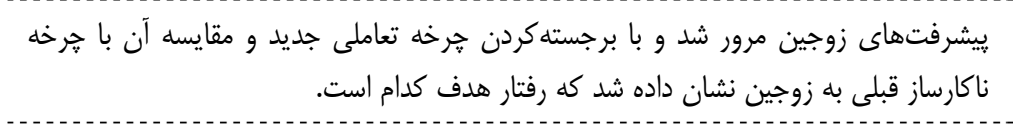 & تقويت مواضع و تثبيت هرخه جديد در كنار & 9 \\
\hline 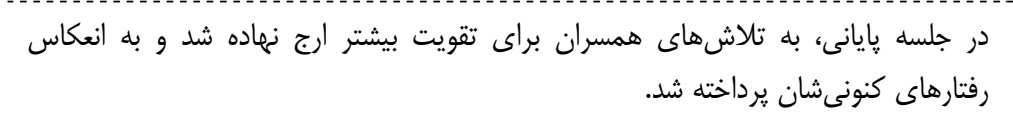 & ايجاد انكَيزه بيشتر براى ارتباط سالم & 1. \\
\hline
\end{tabular}


مفروضههاى تحليل كواريانس شامل: نرمالبودن توزيع

يافته ها

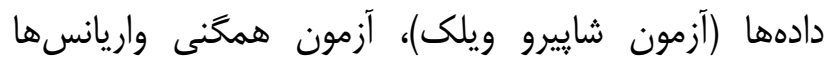
نتايج آزمون كاىاسكوئر در جدول r نشان داد، تفاوت

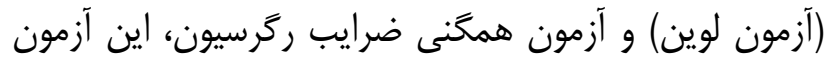

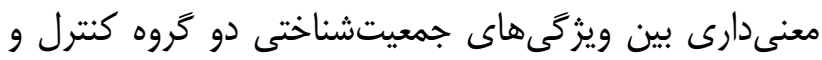

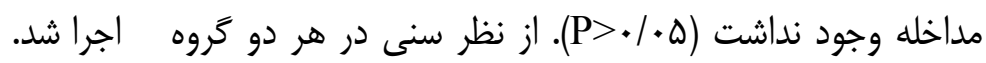

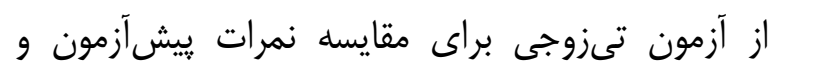

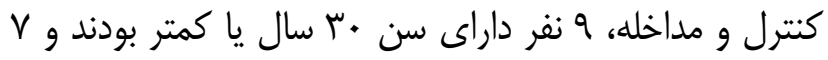

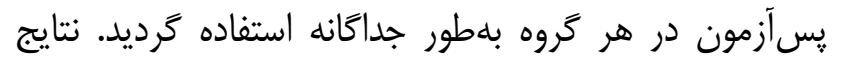

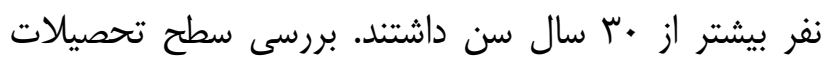

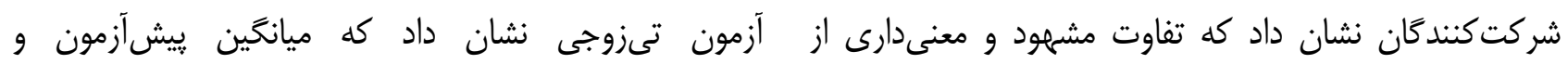

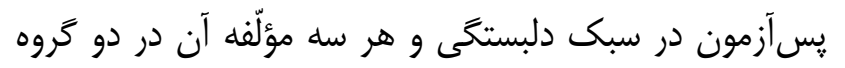

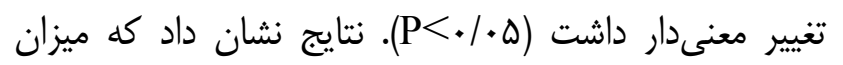
سبك دلبستخى و سه مؤلّفه اضطراب، وابستخى و نزديكى

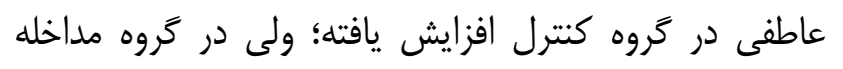
كاهش داشته است. ميانخين كل رضايتمندى جنسى درو در گروه

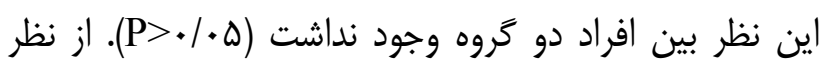

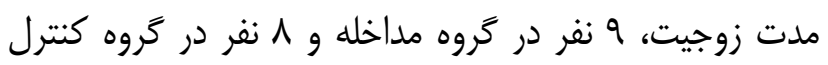

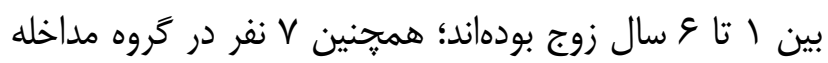

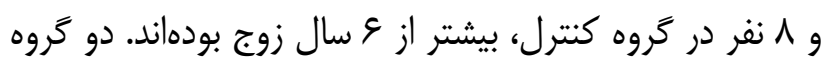
از نظر مدت زوجيت تفاوت مشهودى نداشتند.

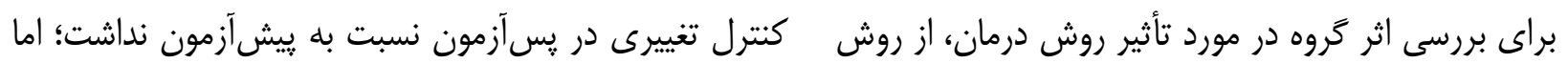

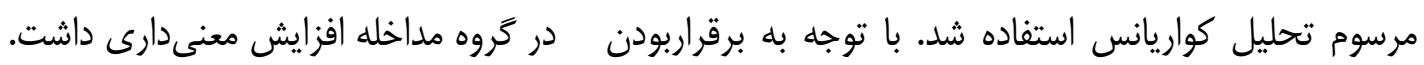
جدول r- مقايسه اطلاعات دموكَ, افيك اعضاى تَروههاى مداخله و كنترل

\begin{tabular}{|c|c|c|c|c|}
\hline \multirow{2}{*}{ سطح معنىدارى } & تروه كنترل & كرووه آزمون & \multirow{2}{*}{ متغير } & \\
\hline & تعداد (درصد) & تعداد (درصد) & & \\
\hline \multirow{2}{*}{1} & $(\Delta \cdot) \wedge$ & $(\Delta \cdot) \wedge$ & زن & \multirow{2}{*}{ جنسيت } \\
\hline & $(\omega \cdot) \wedge$ & $(\Delta \cdot) \wedge$ & مرد & \\
\hline \multirow{4}{*}{.$/ 4 T}$. & $(T Q))^{c}$ & $(r) / r) \Delta$ & r ro-r. & \multirow{4}{*}{ سن } \\
\hline & ه & $(T \Delta) r^{c}$ & צץ-•" سال & \\
\hline & $(r \Delta))^{c}$ & $(T \Delta) \Gamma^{c}$ & וז-"W سال & \\
\hline & س & $(\mid N / \Lambda) r$ & بالاتر از هَ سال & \\
\hline \multirow{4}{*}{$\cdot / 1 \Delta S$} & $(M / \Lambda)^{\mu}$ & $(I r / \Delta) r$ & دييلم & \multirow{4}{*}{ تحصيلات } \\
\hline & $(\Gamma) / T) \Delta$ & $(\Gamma / T) \Delta$ & كاردانى & \\
\hline & $(r \Delta) r^{c}$ & $(r V / \Delta) q$ & كارشناسى & \\
\hline & $(r \Delta) F$ & $(N / \Lambda)^{r}$ & تحصيلات تكميلى & \\
\hline \multirow{4}{*}{$\cdot /$ TDV } & س & $(T \Delta){ }^{c}$ & 1-r سال & \multirow{4}{*}{ مدت زوجيت } \\
\hline & $(\Psi / T) \Delta$ & $(\Gamma) / T) \Delta$ & ع ع-ع سال & \\
\hline & $(T \Delta))^{c}$ & $(\mathrm{~N} / \Lambda)^{\mu}$ & 9-V (1) & \\
\hline & $(T \Delta))^{c}$ & $(T \Delta))^{c}$ & بالاتر از 9 سال & \\
\hline
\end{tabular}

rT. 
بررسى مؤلفههاى رضايتمندى جنسى نشان داد كه

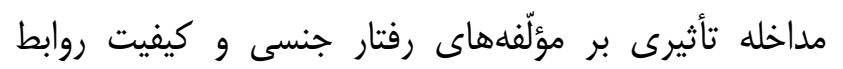

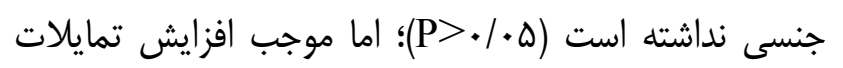

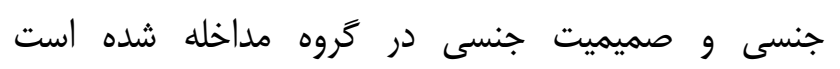
$(\mathrm{P}<\bullet / \cdot \Delta)$

بررسى ميانگين سبك دلبستخى نشان داد كه در گروه

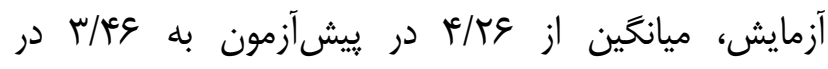

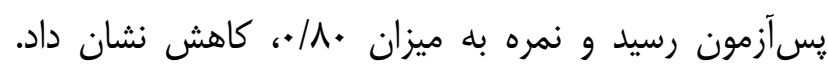

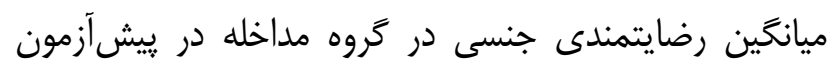

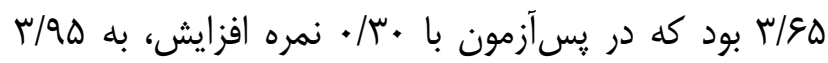

$$
\text { رسيد. }
$$

نتايج نشان داد كه مداخله موجب كاهش ميانخين مؤلّفه

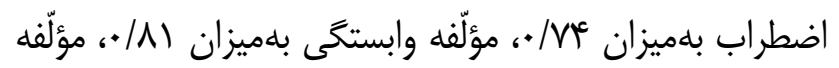

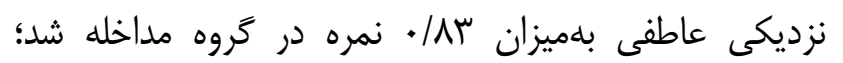

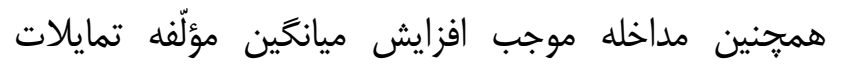

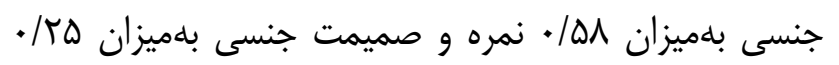
نمره در گروه مداخله ترديد.
جدول س، يافتههاى توصيفى مربوط به سبك دلبستخى و رضايتمندى جنسى را نشان مى دهد. بر اساس نتايج ارائهشده

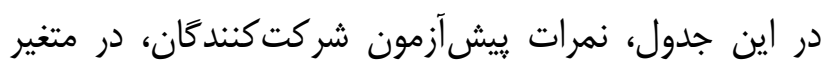

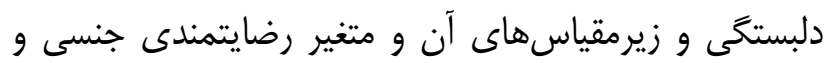

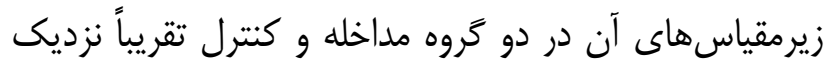

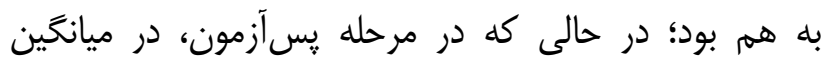

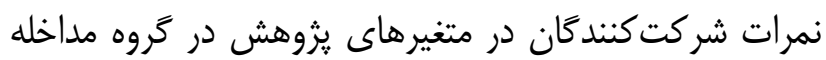
تغيير محسوسى ايجاد شد.

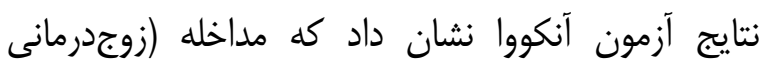

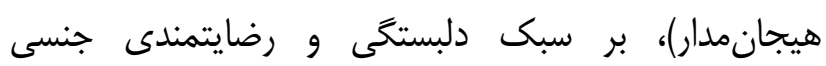

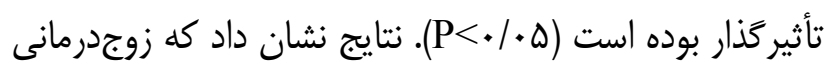
هيجانمدار موجب كاهش معنىدار سبك دلبستخى و افزايش معنى دار رضايتمندى جنسى در زوجين شده است.

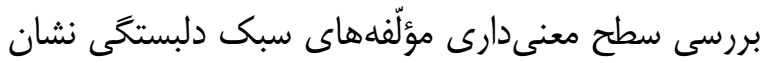

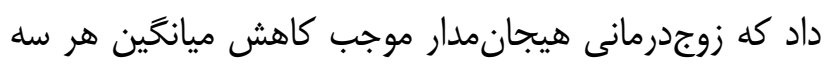

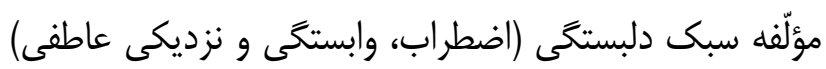

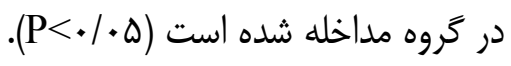

جدول بـ مقايسه ميانكَين نمرههاى سبكى دلبستَى و رضايتمندى جنسى در تروههاى مداخله و كنترل، قبل و بعد از مداخله

\begin{tabular}{|c|c|c|c|c|c|c|c|c|c|}
\hline \multirow{2}{*}{ آزمنى دارى } & \multirow{2}{*}{ تمنى سطارى } & \multirow{2}{*}{ ميانغَين } & \multicolumn{2}{|c|}{ تحروه مداخله } & \multirow{2}{*}{ تمنى سَّارى } & \multirow{2}{*}{ ميانتَين } & \multicolumn{2}{|c|}{ تَروه كنترل } & \multirow{2}{*}{ متغيرها } \\
\hline & & & صِ آزمون & ييشآزمون & & & پِسآزمون & ييشآزمون & \\
\hline$<\cdot / \cdot .1$ & $<\cdot / \cdot \cdot 1$ & $-\cdot / V^{c}$ & r & 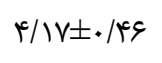 & $<\cdot / . .1$ & $+\cdot|\wedge|$ & $\uparrow / ৭ \wedge \pm \cdot / \Delta \Delta$ & $\uparrow / / V \pm \cdot / \kappa q$ & اضطراب \\
\hline$<\cdot / \cdot \cdot 1$ & $<\cdot / \cdot \cdot 1$ & $-\cdot|\wedge|$ & $\Gamma / T \mathrm{~T} \pm \cdot / \mathrm{G}$ & $F / \lambda \pm \cdot / \mu$ & $<\cdot / \cdot \cdot 1$ & $+\cdot / \Delta \Delta$ & $\Gamma / Q) \pm \cdot / \Delta F$ & 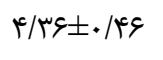 & وابستخى \\
\hline$<\cdot / \cdot .1$ & $<\cdot / \cdot .1$ & $-\cdot / A r$ & $r / \varepsilon \cdot \pm \cdot \pi / r$ & $\tau / \mathscr{c} \Psi \pm \cdot / r V$ & . & $+\cdot|\Delta|$ & $\varphi / \uparrow q \pm \cdot / q q$ & $\mathbb{E} / \mathscr{F} \pm \cdot / \kappa \phi$ & نزديكى عاطفى \\
\hline$<\cdot / \cdot \cdot 1$ & $<\cdot / \cdot .1$ & $-\cdot / \Lambda$ & $\Gamma / \uparrow \& \pm \cdot / / V$ & T/RGD./TQ & $<\cdot / \cdot \cdot 1$ & $+\cdot / 9 T$ & $ץ / q \uparrow \pm . / \mu \wedge$ & سr/ & سبك دلبستخى \\
\hline r... & $<\cdot / \cdot \cdot \mid$ & $+\cdot / \Delta \Lambda$ & $r / . r \pm . / F r$ & $r /\{\uparrow \pm \cdot|\Lambda|$ & $\cdot|\Lambda|$ &.$- / 10$ & $r / Q \Lambda \pm \cdot / V \checkmark$ & $r / r \pm \cdot / \Lambda r$ & تمايلات جنسى \\
\hline.$/ 19 \Delta$ & .1119 &.$+ / 19$ & $\mu / 94 \pm \cdot / 9 q$ & $r / ז \wedge \pm \cdot / q r$ & ./Avq &.$- / .4$ & $r / r \Lambda \pm \cdot / V \Lambda$ & $\Gamma / \Gamma \cdot \pm \cdot(\Lambda)$ & رفتار جنسى \\
\hline 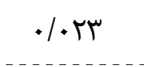 & .1 .40 & $+\cdot / r \Delta$ & $r / V \cdot \pm \cdot / \wedge V$ & $F / F \Delta \pm \cdot / q F$ & . TTS & -.11 & $\varphi / 1 \cdot \pm \cdot / \Delta$. & $r / T \cdot \pm \cdot / q T$ & صميميت جنسى \\
\hline$\cdot / D Q T$ & $.1 .9 V$ & $+\cdot / 1 \mathrm{~V}$ & $r / F \cdot \pm \cdot / v \cdot$ & $r / \mu \Psi \cdot / q 1$ & $. / 9 \Delta)^{\mathrm{C}}$ &.- .1 .1 & $r / r \Delta \pm \cdot / \Lambda$. & $r / r g \pm \cdot / A r$ & كيفيت روابط جنسى \\
\hline$<\cdot / \cdot \cdot 1$ & $.1 .4 q$ & $+\cdot / \mu$ & $r / ৭ \Delta \pm \cdot / \kappa$. & $\Gamma / \& \Delta \pm \cdot / \mu)$ & . & -.1 .0 & $r / \tau \cdot \pm \cdot / r \cdot$ & $\Gamma / \uparrow^{c} \Delta \pm \cdot / \mu$ & رضايتمندى جنسى \\
\hline
\end{tabular}




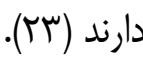

نكته مهمى كه در يافتههاى يخوهش مشاهده مىشود

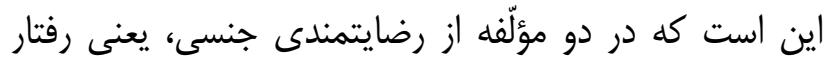

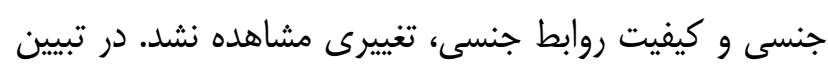

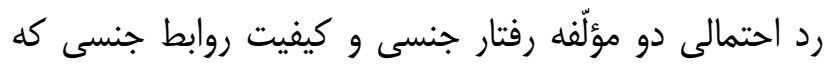

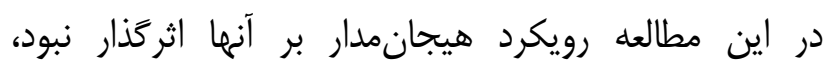
مى توان به دلايل زير اشاره كرد:

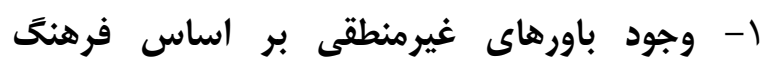

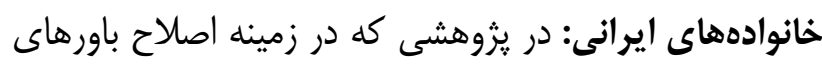

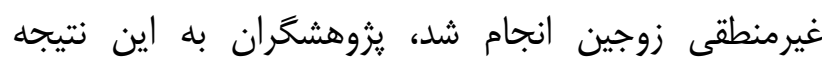

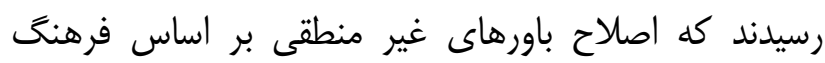
خانوادههاى ايرانى، بر افزايش رضايت جنسى تأثير معنى دارى إنى

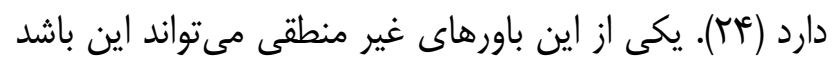

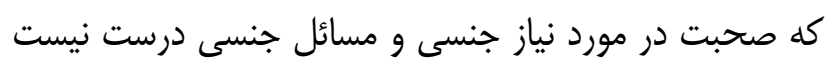

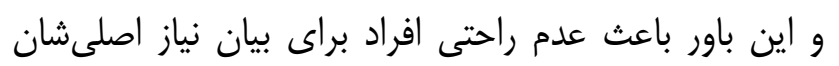

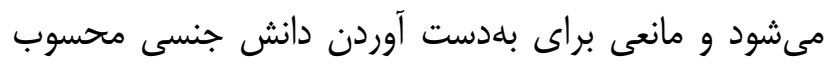
مى كردد.

r- در يزوهشى نشان داده شد، بين دانش جنسى ود ودم

نخرش جنسى، همبستخى مثبت و معنى دارى وجود دارد؛ اما

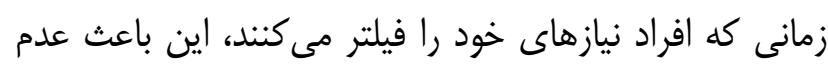

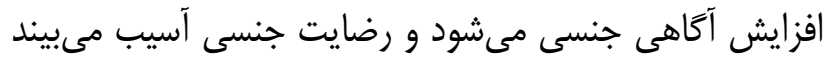

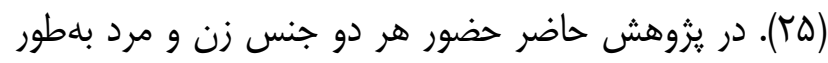

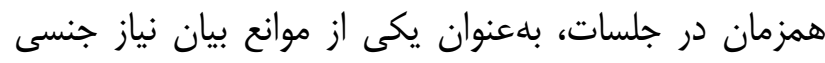

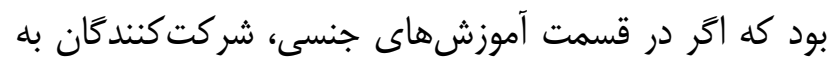

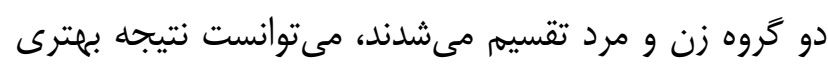

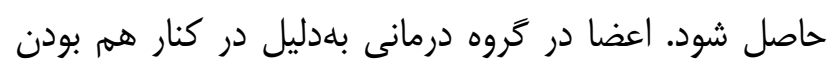

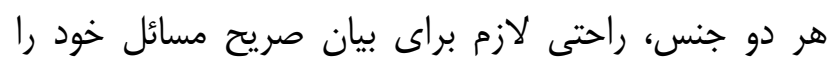

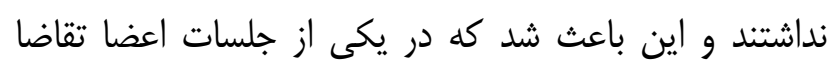

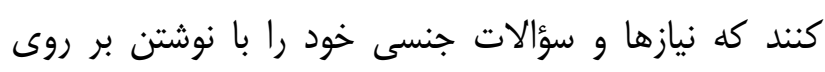

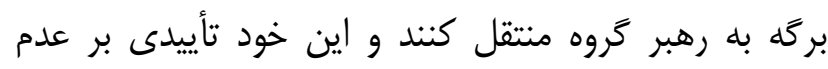

راحتى زوجين براى بيان نيازهاى خود در جلسات اول بود

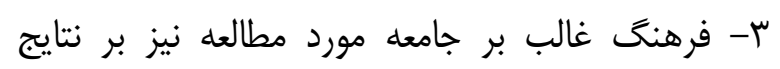

نتايج اين يزوهش نشان داد كه زوجدرمانى هيجانمدار،

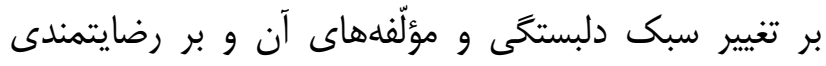

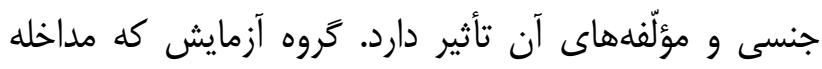

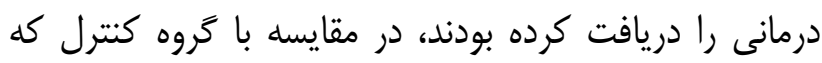

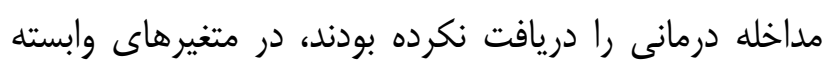

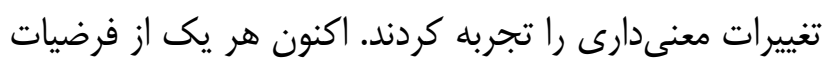
بررسى مىشود:

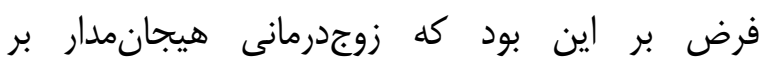
رضايتمندى جنسى و مؤلّفهاى آن تأثير دارد. يافتهها حاكى

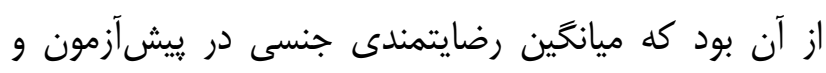

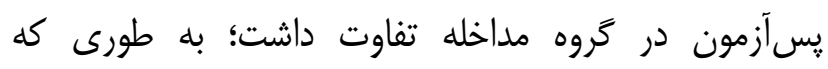

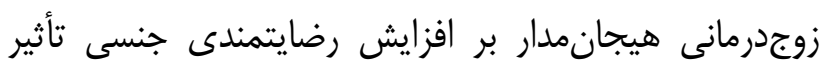

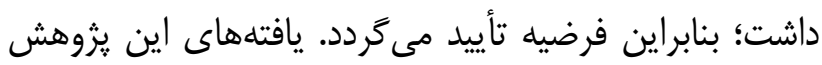

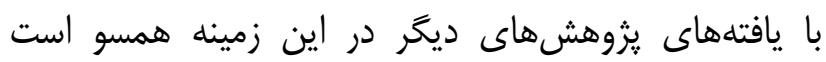
(19-19)

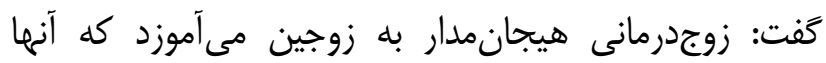

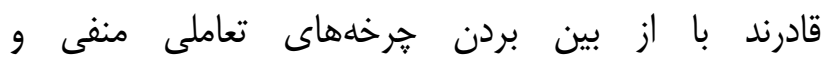

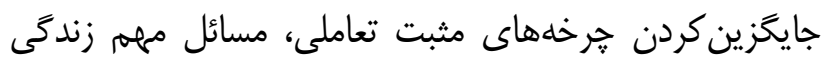

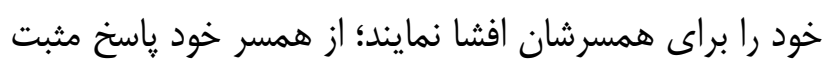

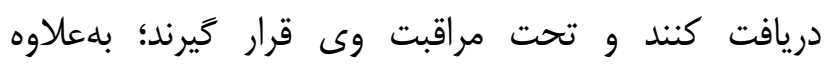
تعاملهاى كلامى و غير كلامى خود را افزايش دهند و وافت افكار،

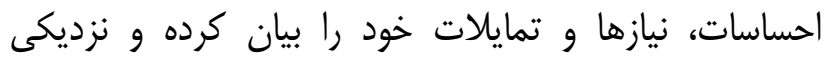

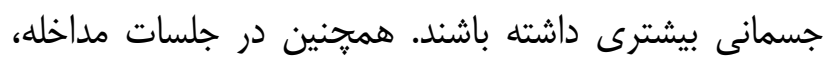

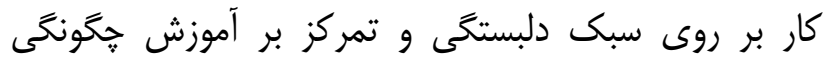

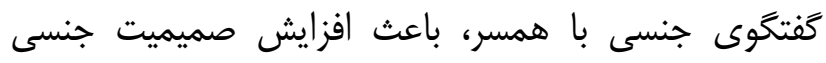

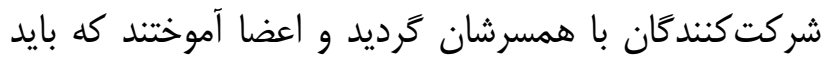

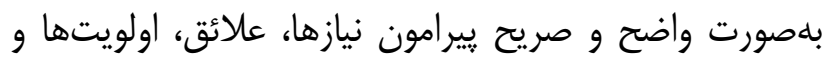

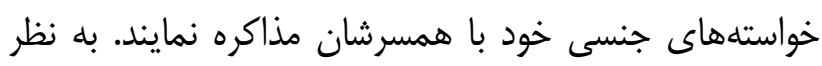
Butzer بين زوجين، از ميزان صميميت جنسى آنها مى كاهد؛ زوجينى إنى

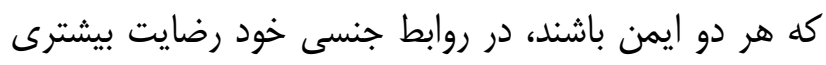




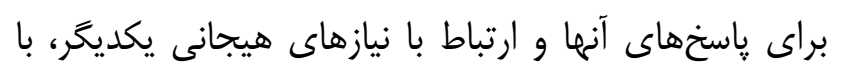

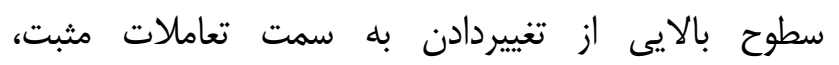
صميميت، خودافشايى قدرتمند هيجانى و باسخخهاى همدلانه و كرم، ارتباط دارد (و (ب).

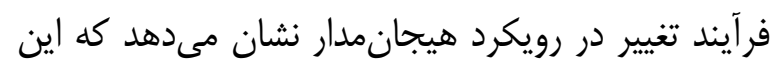

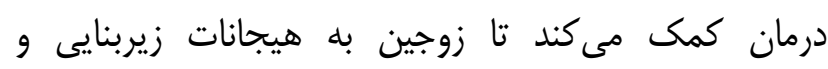
آسيبديده اوليه دسترسى بيدا كنند و بتوانند آن را ابراز كنندات زينان آشكارسازى هيجانات آسيبيذير زيربنايى در شكستن خرخد

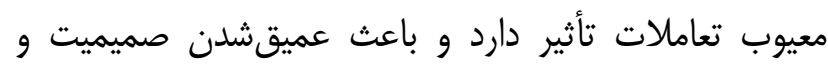

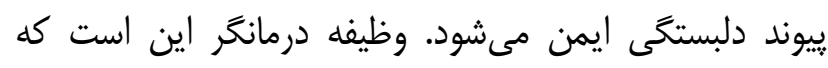

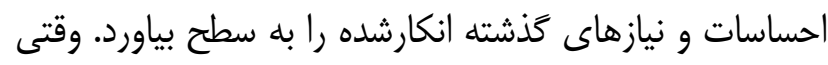

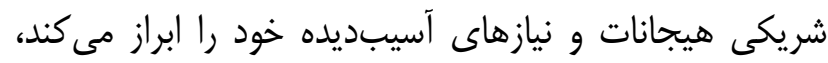

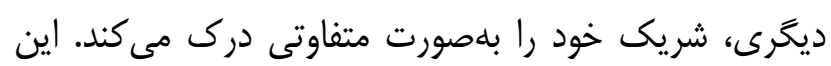

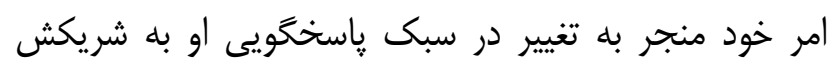
مىشود. يزوهش حاضر نيز داراى محدوديتهايى بود كه از جمله

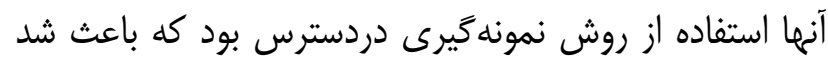

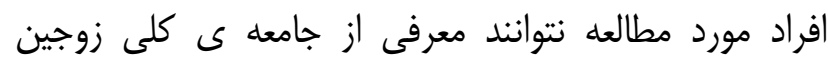

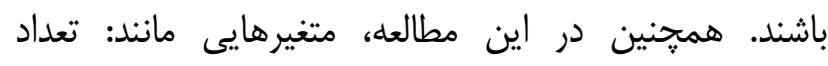

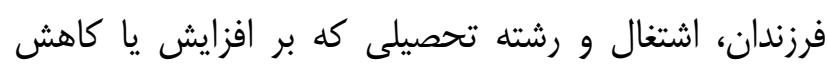

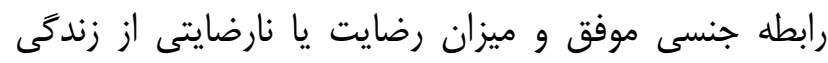

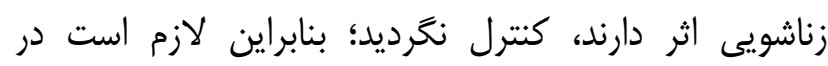
تعميم نتايج بلهدست آمده احتياط شود.

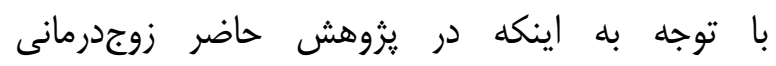

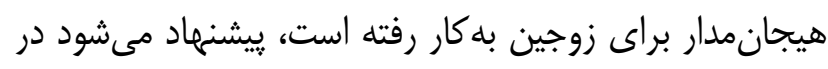

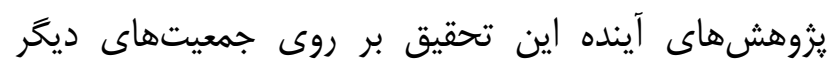

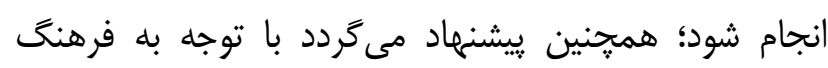

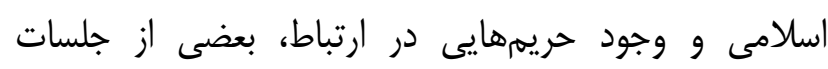

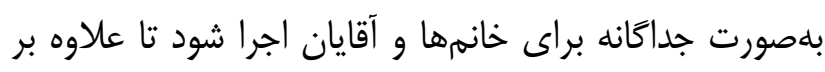
بيان مشكلات، تأثير كذارى آموزش هان بان بيشتر باشند.
تحقيق اثركذار بود و يكى از مواردى است كه متتوان در

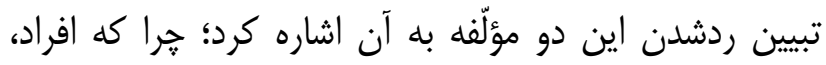

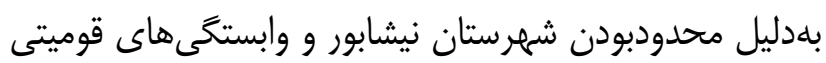

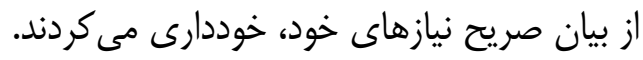

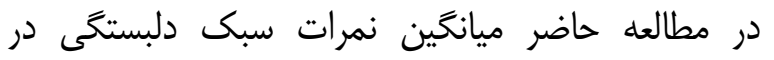

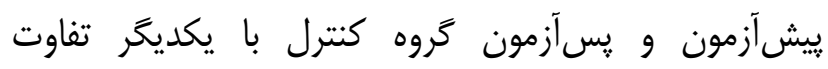

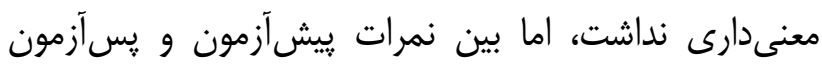

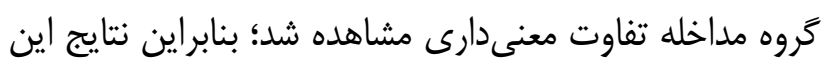

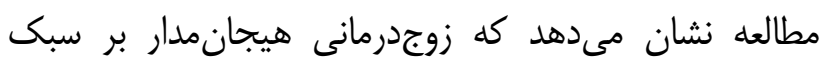

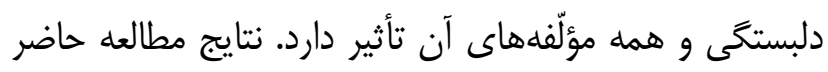

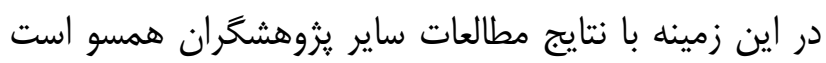
(1) در تبيين تأييد احتمال اين فرضيه مىتوان به نحوه

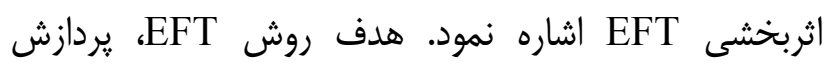

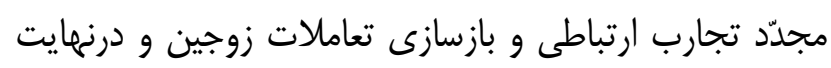

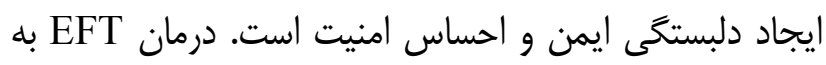

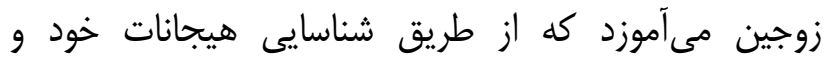

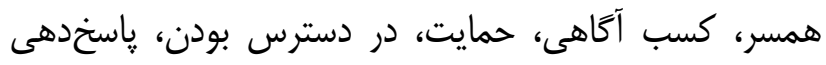

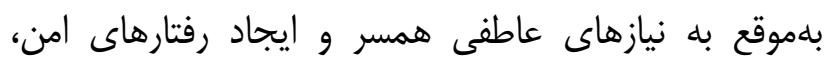
مهارتهاى ارتباطى و صميميت خود را ارتقا دهند.

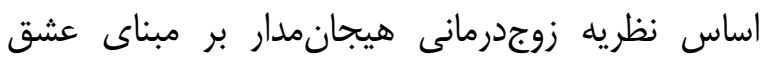

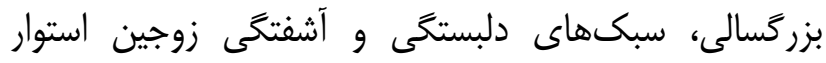

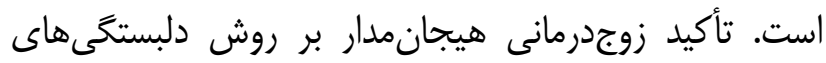

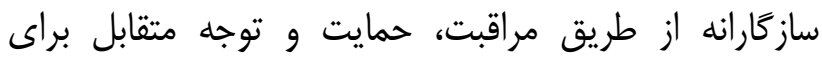

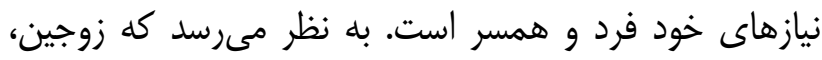

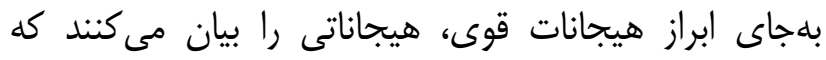

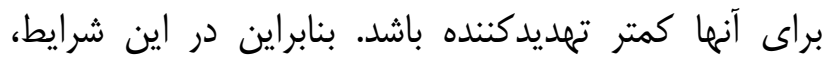

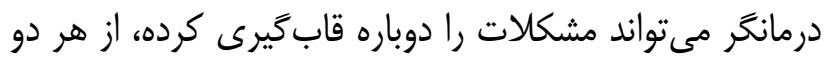

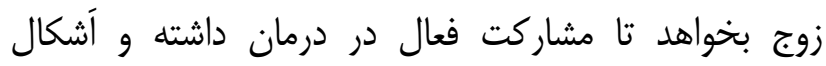

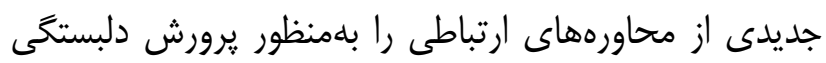

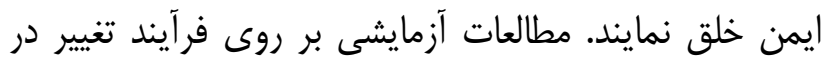
زوجدرمانى هيجانمدار نشان داده است كه كشف زوريند 


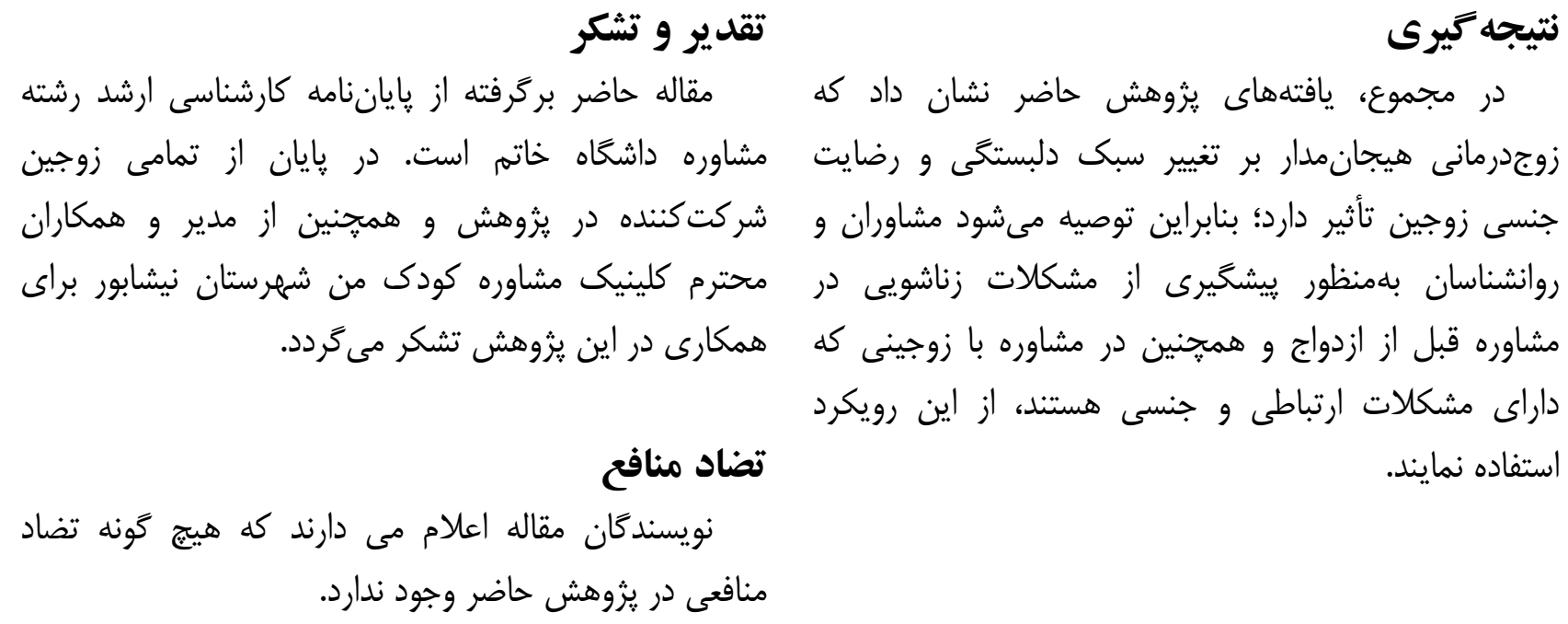

1- Sprecher S, Cate RM. Sexual satisfaction and sexual expression as predictors of relationship satisfaction and stability. In: Harvey JH, Wenzel A, Sprecher S (Eds.). The handbook of sexuality in close relationships. Mahwah, NJ: Erlbaum; 2004. pp: 235-56.

2- Rosen NO, Muise A, Bergeron S, Delisle I, Baxter ML. Daily Associations Between Partner Responses and Sexual and Relationship Satisfaction in Couples Coping with Provoked Vestibulodynia. J Sex Med. 2015; 12(4): 1028-39. doi: 10.1111/jsm.12840.

3- Bradley RH, Corwyn RF. Life Satisfaction among European American, African, American Chinese American, Mexican American, and Dominican American Adolescents. Int J Behav Dev. 2004; 28(5): 385-400. DOI: $10.1080 / 01650250444000072$

4- Rapoza KA, Baker AT. Attachment Styles, Alcohol, and Childhood Experiences of Abuse: An Analysis of Physical Violence in Dating Couples. Violence Vict. 2008; 23(1): 52-65. DOI: 10.1891/0886-6708.23.1.52 .

5- Berry K, Barrowclough C, Wearden A. A review of the role of adult attachment style in psychosis: unexplored issuesand questions for further research. Clin Psychol Rev. 2007; 27(4): 458-75. DOI: 10.1016/j.cpr.2006.09.006

6- Mazaheri MA. The role of adult attachment in marriage. Psychology. 2000; 4(3): 318-86. [Persian]

7- Feeney JA, Karantzas GC. Couple conflict: insights from an attachment perspective. Curr Opin Psychol. 2017; 13, 60-4. doi: 10.1016/j.copsyc.2016.04.017

8- Gouvernet B, Rebelo T, Sebbe F, Hentati Y, Yougbaré S, Combaluzier S, et al. Is pornography pathogen by itself? Study of the role of attachment profiles on the relationship between pornography and sexual satisfaction. Sexologies. 2017; 26(3): e27-33. Doi : 10.1016/j.sexol.2016.10.002

9- Johnson SM. Creating connection: the practice of emotionally focused couple therapy. New York: Brunner Routledge; 2004.

10- Wiebe SA, Johnson SM. A review of the research in emotionally focused therapy for couples. Fam Process. 2016; 55(3): 390-407. doi: 10.1111/famp.12229.

11- Johnson SM. The contribution of emotionally focused couple therapy. J Contemp Psychother. 2007; 37(1): 47-52.

12- Greenberg LS, Goldman RN. Integrating love and power in emotion - focused couple therapy. European psychotherapy. 2007; 7(1): 117-35.

13- Montagno M, Svatovic M, Levenson H. Short-term and long-term effects of training in emotionally focused couple therapy: professional and personal aspects. J Marital Fam Ther. 2011; 37(4): 380-92. DOI: 10.1111/j.17520606.2011.00250.x 
14- Greenberg LS. Emotion-focused therapy of depression. Person-Centered \& Experiential Psycho- therapies. 2017; 16(2 Pt I): 106-17. doi: 10.1080/14779757.2017.1330702

15- Ramezani MA, Ahmadi K, Besharat MA, Noohi S, Ghaemmaghami A, Jamshidnejad N. A comparison between the effectiveness of emotion-focused couples therapy and Masters-Johnson's sex therapy in treatment of hypoactive sexual desire disorder in couples. J Sex Med. 2017; 14(4): e108.

16- Rostami M, Taheri A, Abdi M, Kermani N. The Effectiveness of Instructing Emotion-focused Approach in Improving the Marital Satisfaction in Couple. Procedia Soc Behav Sci. 2014; 114: 693-8. DOI: 10.1016/j.sbspro.2013.12.769

17- Shahkarami M, Rasooli M, Ghobadian M, Moradizadeh S, Hadavi N. Effectiveness of Emotionally Focused Couple Therapy on Reduction of Marital Burnout among Referent Females to Psychological Counseling Centers. J Appl Environ Biol Sci. 2014; 4(2s): 158-62.

18- Priest JB. Emotionally Focused Therapy as Treatment for Couples With Generalized Anxiety Disorder and Relationship Distress. J Couple Relatsh Ther. 2013; 12(1): 22-37. DOI: 10.1080/15332691.2013.749763

19- Hosseinizand M, Shafiabadi A, Soudani M. Effectiveness of islamic couple therapy on sexuall intimacy among couples attending in Nikan Clinic Tehran. Journal of Social Psychology (New Findings in Psychology). 2013; 7(25): 27-39. [Persian]

20- Pouurakbar S. Surveying the role of personality traits in exhalation of the relationship between sexual satisfactions with marital satisfaction [Dissertation]. Iran, Tehran: University of Tarbiat moddares; 2011. [Persian]

21- Pakdaman Sh. Investigating the Relationship between Attachment Styles and Societalism in Adolescence [Dissertation]. Iran, Tehran: University of Tehran; 2002. [Persian]

22- Johnson S. Emotionally-Focused Couple Therapy. Translated by: Hosseini B. Tehran: Jangle Press; 2010. pp: 189276. [Persian]

23- Butzer B, Campbell L. Adult attachment, sexual satisfaction, and relationship satisfaction: A study of married couples. Pers Relatsh. 2008; 15(1): 141-54. DOI: 10.1111/j.1475-6811.2007. 00189.x

24- Bazoei Z. Effect of education on the reformation of irrational beliefs based on Iranian family culture on sexual intimacy and sexual satisfaction of married women in Tehran. [Dissertation]. Iran, Tehran: Allameh Tabatabaei University; 2014. [Persian]

25- Nooranipour R, Besharat MA, Yousefi E. The Relationship between Knowledge and Sexual Attitude with Marital Satisfaction in Couples Residing in the Young Researchers' Complex of Shahid Beheshti University. Journal of Counseling Research. 2007; 6(24): 27-40. [Persian]

26- Goldman RN, Greenberg L. Working with identity and self-soothing in Emotion-Focused Therapy for Couples. Fam Process. 2013. 52(1): 62-82. doi: 10.1111/famp.12021. 